\title{
Chromosomal instability predicts metastatic disease in patients with insulinomas.
}

Citation for published version (APA):

Jonkers, Y. M. H., Claessen, S. M. H., Perren, A., Schmid, S., Komminoth, P., Verhofstad, A. A., Hofland, L. J., de Krijger, R. R., Slootweg, P. J., Ramaekers, F. C. S., \& Speel, E. J. M. (2005). Chromosomal instability predicts metastatic disease in patients with insulinomas. Endocrine-Related Cancer, 12, 435447. https://doi.org/10.1677/erc. 1.00960

Document status and date:

Published: 01/01/2005

DOI:

10.1677/erc. 1.00960

Document Version:

Publisher's PDF, also known as Version of record

\section{Please check the document version of this publication:}

- A submitted manuscript is the version of the article upon submission and before peer-review. There can be important differences between the submitted version and the official published version of record.

People interested in the research are advised to contact the author for the final version of the publication, or visit the DOI to the publisher's website.

- The final author version and the galley proof are versions of the publication after peer review.

- The final published version features the final layout of the paper including the volume, issue and page numbers.

Link to publication

\footnotetext{
General rights Owners
rights.

- You may freely distribute the URL identifying the publication in the public portal. please follow below link for the End User Agreement:

www.umlib.nl/taverne-license

Take down policy

If you believe that this document breaches copyright please contact us at:

repository@maastrichtuniversity.nl

providing details and we will investigate your claim.
}

Copyright and moral rights for the publications made accessible in the public portal are retained by the authors and/or other copyright owners and it is a condition of accessing publications that users recognise and abide by the legal requirements associated with these

- Users may download and print one copy of any publication from the public portal for the purpose of private study or research.

- You may not further distribute the material or use it for any profit-making activity or commercial gain

If the publication is distributed under the terms of Article $25 \mathrm{fa}$ of the Dutch Copyright Act, indicated by the "Taverne" license above, 


\title{
Chromosomal instability predicts metastatic disease in patients with insulinomas
}

\author{
Y M H Jonkers, S M H Claessen, A Perren ${ }^{1}$, S Schmid ${ }^{1}, P$ Komminoth ${ }^{2}$, \\ $A$ A Verhofstad ${ }^{3}, L J$ Hofland ${ }^{4}, R R$ de Krijger $^{5}, P J$ Slootweg $^{6}$, \\ F C S Ramaekers and E-J M Speel
}

\author{
Department of Molecular Cell Biology (Box 17), Research Institute for Growth and Development, University of Maastricht, PO Box \\ 616, 6200 MD, Maastricht, The Netherlands \\ ${ }^{1}$ Department of Pathology, University Hospital, Zurich, Switzerland \\ ${ }^{2}$ Department of Pathology, Hospital Baden, Switzerland \\ ${ }^{3}$ Department of Pathology, University Medical Center, Nijmegen, The Netherlands \\ ${ }^{4}$ Department of Internal Medicine, University Medical Center, Rotterdam, The Netherlands \\ ${ }^{5}$ Department of Pathology, University Medical Center, Rotterdam, The Netherlands \\ ${ }^{6}$ Department of Pathology, University Medical Center, Utrecht, The Netherlands
}

(Requests for offprints should be addressed to Y M H Jonkers; Email: Y.Jonkers@ MOLCELB.unimaas.nl)

\begin{abstract}
Endocrine pancreatic tumors (EPTs) comprise a highly heterogeneous group of tumors with different clinical behavior and genetic makeup. Insulinomas represent the predominant syndromic subtype of EPTs. The metastatic potential of insulinomas can frequently not be predicted using histopathological criteria, and also molecular markers indicating malignant progression are unreliable because of the small number of cases per subtype studied so far. For the identification of reliable indicators of metastatic disease, we investigated 62 sporadic insulinomas (44 benign and 18 tumors with metastases) by means of comparative genomic hybridization (CGH). In addition, the role of MEN1 (multiple endocrine neoplasia type 1) gene mutations was determined to assess specific chromosomal alterations associated with dysfunction of this endocrine tumor-related tumor suppressor gene. Only one case with a somatic MEN1 mutation was identified (1527del7bp), indicating that the MEN1 gene plays a minor pathogenic role in sporadic insulinomas. $\mathrm{CGH}$ analysis revealed that the total number of aberrations per tumor differs strongly between the benign and the malignant group (4.2 vs $14.1 ; P<0.0001)$. Furthermore, chromosome $9 q$ gain was found to be the most frequent aberration in both benign and malignant insulinomas, whereas chromosome $6 q$ losses and 12q, 14q and 17pq gains are strongly associated with metastatic disease. Our study shows that chromosomal instability, as defined by $\geq 5$ gains together with $\geq 5$ losses, or total number of gains and losses $\geq 8$, rather than parameters such as tumor size and proliferation index, is the most powerful indicator for the development of metastatic disease in patients with sporadic insulinoma.
\end{abstract}

Endocrine-Related Cancer (2005) 12 435-447

\section{Introduction}

Endocrine pancreatic tumors (EPTs) represent 1-2\% of all pancreatic neoplasms and are separated on the basis of their clinical manifestation into functioning (syndrome-related) and non-functioning tumors. Insulinomas are the most frequently detected functioning EPTs. They show evidence of $\beta$-cell differentiation and clinical symptoms of hypoglycemia due to uncontrolled insulin production. Strategies for insulinoma treatment include surgical resection and, in the case of palliation, chemotherapy and anti-hypoglycemic medication (Chun \& Doherty 2001, Komminoth et al. 2004). The only feature that separates benign from malignant disease is organ and/or lymph node infiltration or distant metastases (Komminoth et al. 2004). 
When only a primary lesion is identified, however, no reliable markers for malignancy are available. At best a tumor diameter $\geq 2 \mathrm{~cm}$, an increased mitotic index and necrosis seem to indicate an increased risk for malignancy (Hochwald et al. 2002). It is obvious that new indicators that reliably determine prognosis of malignancy are urgently needed.

Little is known about the molecular pathogenesis of insulinomas (Leothela et al. 2003, Moore et al. 2003). So far, only limited numbers of predominantly benign insulinomas have been genetically analyzed, indicating the involvement of the MEN1 (multiple endocrine neoplasia type 1) gene at 11q13, and gain of chromosome 9q in early tumorigenesis (Zhuang et al. 1997, Görtz et al. 1999, Cupisti et al. 2000, Speel et al. 2001). MEN1 is the susceptibility gene of the autosomal dominant familial MEN1 cancer syndrome (Schussheim et al. 2001). Patients with an inherited mutation in this gene develop tumors in endocrine organs, including insulinomas in $10-35 \%$ of cases. Evidence for a direct involvement of the MEN1 tumor suppressor gene in early insulinoma development was provided by a transgenic mouse model with a hemizygous deletion of the MEN1 gene in pancreatic $\beta$-cells. Somatic deletion of the second allele resulted in insulinoma formation with multiple progression features (Bertolino et al. 2003). However, a role for the $M E N 1$ gene in human sporadic insulinomas is unclear. Its mutation rate seems to be rather low, ranging from 0 to $17 \%$ in the different studies described so far (Zhuang et al. 1997, Görtz et al. 1999, Cupisti et al. 2000, and references therein). On the other hand, we have recently shown that in a small series of predominantly benign insulinomas, gain of chromosome $9 \mathrm{q}$ is the most common alteration identified by comparative genomic hybridization (CGH) in $50 \%$ of insulinomas with a diameter $\leq 2 \mathrm{~cm}$, with the smallest region of gain being 9q34 (Speel et al. 2001).

Chromosomal markers with high potential to discriminate malignant from benign insulinomas have not been described so far. DNA cytometry data suggest that DNA ploidy is unlikely to provide useful prognostic information for patients with insulinomas, because large ploidy changes are seldomly detected (Graeme-Cook et al. 1990, Böttger et al. 1997). The few malignant insulinomas that have been genetically analyzed by molecular allelotyping and CGH were mainly part of larger studies on EPTs, including different functioning and non-functioning subtypes (Chung et al. 1998, Speel et al. 1999, 2001, Stumpf et al. 2000, Zhao et al. 2001). Several markers for malignant or metastatic progression in EPTs have been indicated, in particular loss of chromosomes 1 (Ebrahimi et al.
1999), 3p (Chung et al. 1997, Hessman et al. 1999, Barghorn et al. 2001a), 3q (Chung et al. 1998, Guo et al. 2002), 6q22-24 (Barghorn et al. 2001b), 11q13 (Hessman et al. 1999), 17p (Beghelli et al. 1998), 22q (Chung et al. 1998, Wild et al. 2002) and X (Missiaglia et al. 2002). These do, however, require further validation in larger series of individual EPT subtypes, including insulinomas.

The objective of the present study was to determine by CGH the occurrence of DNA copy number losses and gains along all chromosome arms in benign and malignant insulinomas in order to asses the chromosomal markers with the highest potential to predict metastatic disease. These markers will be compared with the best indicators of increased risk for malignancy suggested by the WHO, i.e. tumor size and proliferation index. For this purpose we have extended our previously analyzed collection of mainly benign insulinomas (Speel et al. 2001) to a large group of 62 tumors, including 18 malignant cases. In addition, these tumors were examined for MEN1 mutations to assess the impact of this gene in insulinomas, and a possible association of such mutations with particular $\mathrm{CGH}$ profiles.

\section{Materials and methods}

\section{Tumor material and patient data}

Sixty-two insulinomas ( 32 females, mean age $52.1 \pm$ 18.6 years and 30 males, mean age $53.1 \pm 15.7$ years) were selected from the archives of the Departments of Pathology of the University Hospital, Zurich, Switzerland and the University Medical Centers of Rotterdam, Utrecht and Nijmegen, The Netherlands. The study protocol was approved by the institutional ethical committee, and all of the patients gave informed consent. The samples included 59 frozen and three paraffin-embedded insulinomas, which were all sporadic tumors and not associated with the inherited MEN1 syndrome. The tumors were classified according to the most recent WHO classification (Komminoth et al. 2004). All insulinomas had hyperinsulinism followed by a hypoglycemia syndrome. Forty-four of the patients had localized disease, defined by (i) the absence of extra-pancreatic spread of the tumor as evidenced by computed tomography, magnetic resonance imaging or ultrasound scanning, and (ii) a complete absence of hypoglycemia (even during $72 \mathrm{~h}$ fasting) after successful removal of the tumor by surgery. Moreover, during follow-up of at least 1 year, these cases showed neither evidence of recurrent hypoglycemia at follow-up, nor recurrence or metastases by 
radiology. No post-operative adjuvant therapy was given to these patients. Eighteen patients had advanced disease, with tumor spread into the surrounding soft tissue, lymph nodes or liver.

\section{DNA extraction}

DNA extraction was performed as described before (Speel et al. 2001). Genomic DNA from frozen samples was isolated by homogenizing approximately $5 \mathrm{~mm}^{3}$ of each sample prior to proteinase $\mathrm{K}$ treatment and DNA purification using the QIAamp DNA mini kit (Qiagen). Genomic DNA from paraffin-embedded tumor material was isolated from $5-10 \mu \mathrm{m}$ thick tissue sections by this procedure after deparaffination. DNA quality was checked with agarose gel electrophoresis and quantified by spectrophotometry.

\section{CGH and digital image analysis}

CGH was performed with DNA isolated from the 62 insulinoma samples as previously described (Speel et al. 2001). Briefly, $2 \mu \mathrm{g}$ tumor DNA were labeled with Spectrum Green-dUTPs (Vysis, Downers Grove, IL, USA) by nick translation (BioNick labeling kit; Life Technologies). Spectrum Red-labeled normal and sexmatched reference DNA (Life Technologies) was used for co-hybridization. The hybridization mixture consisted of $800 \mathrm{ng}$ Spectrum Green-labeled tumor DNA, $800 \mathrm{ng}$ Spectrum-Red labeled reference DNA and $15 \mu \mathrm{g}$ human Cot-1 DNA (Life Technologies) dissolved in $12 \mu \mathrm{l}$ hybridization buffer $(50 \%$ formamide, $2 \times \mathrm{SSC}, 10 \%$ dextran sulfate, $\mathrm{pH} 7.0$ ). Hybridization was carried out for 3 days at $37^{\circ} \mathrm{C}$ to denatured $(5 \mathrm{~min}$ at $75^{\circ} \mathrm{C}$ in $70 \%$ formamide $/ 2 \times \mathrm{SSC}, \mathrm{pH} 7.0$ ) normal male human metaphase spreads (Vysis). Slides were washed twice at $45^{\circ} \mathrm{C}$ for $5 \mathrm{~min}$ in $50 \%$ formamide/ $2 \times \mathrm{SSC}$, pH 7.0, followed by $5 \mathrm{~min}$ in PBS at room temperature. The chromosomes were counterstained with $0.2 \mu \mathrm{g}$ 4,6-diamidino-2-phenylindole per $\mathrm{ml}$ Vectashield (Vector) for identification.

Digital images were collected from at least ten metaphases using the Metasystems Image Pro System black and white CCD camera (Altlussheim, Germany) mounted on top of a Leica DMRE fluorescence microscope, equipped with DAPI, Spectrum Green, and Spectrum Red filter sets. The software Metasystems ISIS 4.4.25 program was used to calculate average green-to-red ratio profiles for each chromosome. At least ten observations per autosome and five observations per sex chromosome were included in each analysis. Gains and losses of DNA sequences were defined as chromosomal regions where the mean green-to-red fluorescence ratio was above 1.20 and below 0.80 respectively. Over-representations were considered amplifications when the fluorescence ratio values in a subregion of a chromosomal arm exceeded 1.5. In negative control hybridizations, the mean green-to-red ratio occasionally exceeded the fixed 1.2 cut-off level at the following chromosomal regions: 1p32-pter, 16p, 19 and 22. Gains of these G-C-rich regions were therefore excluded from all analyses.

\section{Statistical analysis of CGH results}

The relationship between genomic alterations and malignancy was analyzed by using the chi-square test or the Fisher exact test, as appropriate. ANOVA was applied to compare the number of genomic alterations between benign and malignant insulinomas. A significance level of $P \leq 0.05$ was chosen.

\section{Confirmation of CGH data by fluorescence in situ hybridization (FISH) analysis}

To validate CGH data independently, touch preparations of 15 insulinomas were subjected to FISH as described previously (Görtz et al. 1999, Speel et al. 2001). The following probe combinations were applied: (i) centromere $9(\mathrm{pMR} 9 \alpha)$ and a cosmid probe (c-ABL8) containing the $c A b l$ gene on chromosome $9 q 34$, (ii) centromere $6(\mathrm{p} 308)$ and a PAC probe $(66 \mathrm{H} 14)$ mapping to the $6 \mathrm{q} 21$ region, and (iii) centromere 11 (pLC11A) and a cosmid probe (c10B11) containing the $M E N 1$ gene at 11q13. Digoxigenin-labeled probes were detected by sheep anti-digoxigenin fluorescein- (Roche) and biotin-labeled probes by two layers of avidinrhodamine connected by a biotinylated goat antiavidin antibody (Vector). Probe visualization and nuclear counterstaining were carried out as described for $\mathrm{CGH}$, and signal scoring and evaluation was performed as described previously (Görtz et al. 1999, Barghorn et al. 2001a).

\section{MEN1 mutation analysis}

MEN1 is a $9 \mathrm{~kb}$ gene which encompasses ten exons (first exon untranscribed). The remaining nine coding exons were examined in 43 insulinomas, 31 benign and 12 malignant tumors, by denaturing gradient gel electrophoresis (DGGE) and single-strand confirmation polymorphism (SSCP), as previously used in several studies (see Table 1) (Görtz et al. 1999, Perren et al. 2002). PCR amplifications were carried out using a programmable thermal cycler (DNA thermal cycler 9600; Perkin Elmer, Norwalk, CT, USA). After initial denaturation at $94{ }^{\circ} \mathrm{C}$ for $5-10 \mathrm{~min}$, the DGGE PCR 
Table 1 Primers used for MEN1 mutation analysis (exons 2-10): modified from a previous study (Görtz et al. 1999)

\begin{tabular}{|c|c|c|c|c|}
\hline Primer & Sequence & Length & Technique & $\begin{array}{c}\text { Annealing } \\
\text { temperature }\left({ }^{\circ} \mathrm{C}\right)\end{array}$ \\
\hline M2cnewF & 5'-CCCGCTTCACCGCCCAGAT-3' & 272 & DGGE & 55 \\
\hline M2cnewR & 5'-TGGAGGGTTTTGAAGAAGTGGGTCA-3' & & & \\
\hline M2newF & 5'-CCTTAGCGGACCCTGGGA-3' & 365 & SSCP & 58 \\
\hline M2newR & 5'-ATAGAGGGCGGCGATGATAGA-3' & & & \\
\hline M2NNF & 5'-TCAACCGCGTCATCCCTACC-3' & 405 & SSCP & 62 \\
\hline M2NR & 5'-CACCTGCCGAACCTCACAAG-3' & & & \\
\hline M3F & 5'-GCACAGAGGACCCTCTTTCAT-3' & 335 & DGGE & 55 \\
\hline M3R & 5'-CTACAGTATGAAGGGGACAAGG-3' & & & \\
\hline M4F & 5'-TGGGCCATCATGAGACATAA-3' & 272 & DGGE & 55 \\
\hline M4R & 5'-CCCACAGCAAGTCAAGTCTG-3' & & & \\
\hline M5F & 5'-CCTGTTCCGTGGCTCATAAC-3' & 148 & DGGE & 55 \\
\hline M5R & 5'-CCTGGCCACTTCССТСTA-3' & & & \\
\hline M6F & 5'-GGTGGCAGCCTGAATTATGA-3' & 213 & DGGE & 55 \\
\hline M6R & 5'-TTAGGGTCTCCCTTCTGCAC-3' & & & \\
\hline M7F & 5'-GGTGGGAGTGGAGATGGAGAGG-3' & 398 & DGGE & 55 \\
\hline M7R & 5'-GGACGAGGGTGGTTGGAAACTG-3' & & & \\
\hline M8NF & 5'-AGACCCCTTCAGACCCTACAGAG-3' & 273 & SSCP & 67 \\
\hline M8R & 5'-CCATCCСTAATCCCGTACATGC-3' & & & \\
\hline M9F & 5'-CTGCTAAGGGGTGAGTAAGAGAC-3' & 334 & DGGE & 55 \\
\hline M9R & 5'-AAAAGTCTGACAAGCCCGTG-3' & & & \\
\hline M10NF & 5'-TTGСТСТСАССТTGСТСТСС-3' & 409 & SSCP & 56 \\
\hline M10NNR & 5'-CTTGATGGCGCTCGAGTT-3' & & & \\
\hline M10a F & 5'-CСTTGCTCTCАССTTGСTCT-3' & 392 & DGGE & 55 \\
\hline M10aR & 5'-TCTGGAAAGTGAGCACTGGA-3' & & & \\
\hline M10b F & 5'-GAGGGTCCAGTGCTCACTTT-3' & 423 & DGGE & 55 \\
\hline M10bR & 5'-GGGTTCTGAGCTGGAGAAAA-3' & & & \\
\hline
\end{tabular}

procedure comprises 40 cycles of denaturation at $94{ }^{\circ} \mathrm{C}$ for $1 \mathrm{~min}$, annealing at $55-67^{\circ} \mathrm{C}$ (see Table 1 ) for $1 \mathrm{~min}$ and extension at $72^{\circ} \mathrm{C}$ for $1 \mathrm{~min}$. Finally, PCR tubes were incubated at $72^{\circ} \mathrm{C}$ for $10 \mathrm{~min}$, at $98^{\circ} \mathrm{C}$ for $8 \mathrm{~min}$, at $55^{\circ} \mathrm{C}$ for $30 \mathrm{~min}$, at $37^{\circ} \mathrm{C}$ for $30 \mathrm{~min}$, and than at $0{ }^{\circ} \mathrm{C}$. The SSCP PCR procedure used the following incubations: 35 cycles of denaturation at $94{ }^{\circ} \mathrm{C}$ for $75 \mathrm{~s}$, annealing at $55-67^{\circ} \mathrm{C}$ (Table 1 ) for $90 \mathrm{~s}$ and extension at $72^{\circ} \mathrm{C}$ for $2 \mathrm{~min}$. Finally, PCR tubes were incubated at $72{ }^{\circ} \mathrm{C}$ for $5 \mathrm{~min}$ and than at $4{ }^{\circ} \mathrm{C}$. PCR amplifications were performed in $50 \mu \mathrm{l}$ reactions with $1 \mathrm{ng}$ genomic DNA, $1 \times$ PCR buffer (Roche), $1.5 \mathrm{mM} \mathrm{MgCl} 2,0.2 \mathrm{mM}$ dNTPs, 50 pmol of each forward and reverse primer and $1 \mathrm{U}$ Amplitaq Gold (Roche).

For the DGGE analysis, 10\% polyacrylamide gels with a $20-80 \%$ (in the case of exon 10a: 50-90\%) denaturing gradient were used. A solution of $100 \%$ chemical denaturant consists of $7 \mathrm{M}$ urea and $40 \%$ formamide. The gels polymerized by adding $1 \%$ ammonium persulfate and $0.05 \%$ tetramethylethylenediamine. Once the gradient gel has polymerized, a $10 \%$ polyacrylamide stacking gel is layered on top of this gradient gel; $10 \mu \mathrm{l}$ PCR-amplified DNA was mixed with $3 \mu \mathrm{l}$ PCR-amplified non-mutated DNA, denatured, annealed, and loaded on the gel together with $5 \mu 1$ Ficoll loading buffer. Electrophoresis was performed at $100 \mathrm{~V}$ for $15 \mathrm{~h}$. After electrophoresis the DNA was visualized by silver staining as previously described (Görtz et al. 1999). Patient DNAs with an altered migration pattern on the DGGE gel were amplified again with primers without a GC-clamp, purified using the QIAquick PCR purification kit (Qiagen), and subjected to DNA cycle sequencing in sense and antisense direction using the TaqDyeDeoxy Terminator Cycle Sequencing kit (Applied Biosystems, Weiterstadt, Germany). This was followed by gel electrophoresis, data collection, and analysis on an automated DNA sequencer (Model 373A; Applied Biosystems).

For SSCP analysis, $10 \mu$ denatured PCR products in stop buffer (95\% formamide, $20 \mathrm{mM}$ EDTA, $0.05 \%$ xylene cyanol, $0.05 \%$ bromophenol blue) were loaded onto non-denaturing $6 \%$ polyacrylamide and $5 \%$ glycerin gels. Electrophoresis was carried out for $16 \mathrm{~h}$ at $8 \mathrm{~W}$ and $500-700 \mathrm{~V}$ at room temperature. After electrophoresis the DNA was visualized by silver staining. PCR products with an altered migration pattern on a SSCP gel were further purified and sequenced as described above for DGGE. 


\section{Ki67 immunohistochemistry}

Ki67 antigen staining was performed on $4 \mu \mathrm{m}$ thick paraffin-embedded tissue sections of 35 insulinomas (22 benign and 13 malignant) as described previously (Wessels et al. 2004). Briefly, sections were deparaffinized and treated with $10 \mathrm{mM}$ citrate buffer $(\mathrm{pH} 6.0)$ in a microwave oven at $600 \mathrm{~W}$ for $15 \mathrm{~min}$ (antigen retrieval). Endogenous peroxidase was inactivated by treatment with $2 \% \mathrm{H}_{2} \mathrm{O}_{2}$ in methanol, followed by incubation in $3 \%$ BSA/PBS to block non-specific binding of antibody conjugates. The sections were incubated for $30 \mathrm{~min}$ at $37^{\circ} \mathrm{C}$ with the mouse monoclonal antibody MIB-1 directed against Ki67 (Dako) at a $1: 100$ dilution in $1 \%$ BSA/PBS, biotin-labeled horse anti-mouse antibody at a 1:200 dilution, and avidin-biotinylated peroxidase complex (Vector Laboratories, Burlingame, CA, USA) at a $1: 50$ dilution in $4 \times$ SSC. Peroxidase activity was visualized using diaminobenzidine $/ \mathrm{H}_{2} \mathrm{O}_{2}$ (Sigma Chemical Co.) and sections were counterstained with hematoxylin and mounted in Entellan (Merck, Darmstadt, Germany). Positive and negative control tissues were included. Positive nuclei were scored in at least 500 cells per sample. The Ki67 labeling index was expressed as the percentage of total cells that were immunopositive.

\section{Results}

\section{General CGH findings}

Figure 1 summarizes the DNA copy number changes detected by $\mathrm{CGH}$ in the 62 insulinomas. Genomic aberrations were found in 33 of the 44 benign and all malignant insulinomas. The average number of chromosomal aberrations per tumor was $7.2 \pm 7.0$ (range 0-28). Chromosomal gains (mean 3.9) were more common than chromosomal losses (mean 2.8), and in two tumors amplifications were identified, i.e. at $9 \mathrm{q} 34$ $(2 \times)$ and 4 p16 $(1 \times)$. The most frequently involved specific genomic changes (in $>20 \%$ of insulinomas) included loss of $\mathrm{Xq}$ in female patients (smallest region of interest (SRI): Xq21) (34\%) and Y in male patients $(43 \%)$, and gains of chromosomes $5 \mathrm{q}, 7 \mathrm{pq}, 9 \mathrm{q}, 17$ and $20 \mathrm{q}$, with the highest frequency of gains for chromosome $9 \mathrm{q}(58 \%)$. Interestingly, gain of chromosome $9 \mathrm{q}$ was detected at approximately the same frequency in both benign and malignant tumors (57 vs $61 \%$ respectively) with $9 \mathrm{q} 34$ most commonly included. When these tumors are compared with those without $9 q$ alterations, the total number of aberrations and gains per tumor were significantly higher in the former group $(9.1 \pm 6.2$ vs $4.6 \pm 7.3, P=0.001$; and $5.5 \pm 4.3$ vs
$1.7 \pm 3.1, P<0.0001$ respectively), with gains of $7 \mathrm{pq}, 9 \mathrm{p}$ and $20 \mathrm{q}$ and loss of Xpq more frequently detected.

The obtained $\mathrm{CGH}$ results were validated in 15 insulinomas by FISH using chromosome 6-, 9- and 11-specific probe sets (Table 2 and Fig. 2). In general, the FISH results confirmed our CGH findings. Tumors without CGH alterations exhibited two or sometimes three copies of chromosome targets, indicating a diploid and triploid DNA content respectively (patients 1-7,11-13), or showed alterations in small subpopulations $(\sim 20 \%)$ of cells (e.g. 11q13 loss in patients 2, 14 and 15). In the case of $9 \mathrm{q}$ alterations, always $\geq 3$ copies of the $9 \mathrm{q} 34$-specific region were observed including two cases with an amplification (patients 10 and 15). Four cases showed tumor subpopulations with aberrant copy numbers of chromosome 9 targets indicating genetic heterogeneity (patients 10-12, 15).

\section{CGH findings, tumor size and proliferation index in relation to metastatic disease}

The total number of chromosomal changes, gains and losses all are strongly associated with malignancy $(P<0.0001$; Table 3A). In addition, marked differences in chromosome-specific alterations were observed between benign and malignant tumors (Fig. 1 and Table 3A). Particularly, losses of 2q, 3q, 6pq and 10q and gains of $4 \mathrm{q}, 7 \mathrm{q}, 12 \mathrm{pq}, 14 \mathrm{q}, 15 \mathrm{q}, 17 \mathrm{pq}$, and $20 \mathrm{pq}$ were detected significantly more frequent in malignant insulinomas, with 6q loss (SRI: 6q14 and 21-22) (0\% in benign vs $67 \%$ in malignant insulinomas), $12 \mathrm{q}$ gain (SRI: $12 \mathrm{q} 24)(2 \%$ vs $50 \%), 14 \mathrm{q}$ gain $(5 \%$ vs $50 \%)$ and $17 \mathrm{pq}$ gain (5 and $9 \%$ vs 56 and $61 \%$ respectively) correlating most evidently (in all cases $P<0.0001$ ). If the tumors are grouped according to the presence of $9 q$ gains, the best common markers for malignancy are $6 \mathrm{q}$ loss and $7 \mathrm{q}, 14 \mathrm{q}$ and $17 \mathrm{q}$ gains (Table 3B). In addition, a number of genomic changes were exclusively identified in one or the other insulinoma group. Interestingly, the group with $9 \mathrm{q}$ gain shows gains and the group without $9 \mathrm{q}$ gain predominantly losses as parameters associated with malignancy (Table 3B).

Apart from differences in genomic alterations, benign insulinomas were found to be significantly smaller than malignant ones (diameter $=1.5$ vs $3.8 \mathrm{~cm}$ respectively, $P<0.0001$ ). Because a diameter of $2 \mathrm{~cm}$ is an important parameter in insulinoma classification, we compared tumors with a size $<2 \mathrm{~cm}$ with tumors $\geq 2 \mathrm{~cm}$ in diameter. This comparison revealed that an increase in the total number of aberrations, gains and losses was significantly correlated with a size $\geq 2 \mathrm{~cm}$ (Table 3A). Loss of 3q, 6pq and 22q and gains of 5pq, 


\section{Benign insulinomas $(n=44)$}

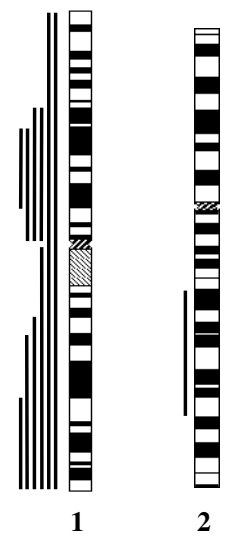

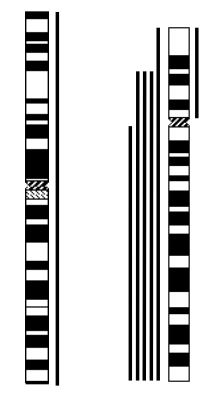

4

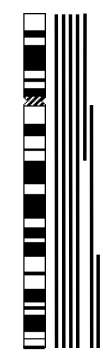

5

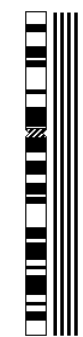

6

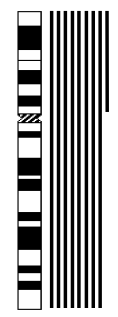

7

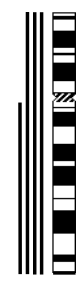

8

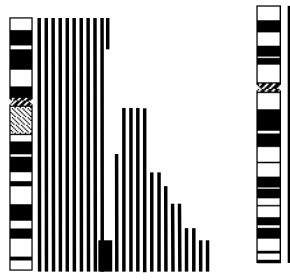

10

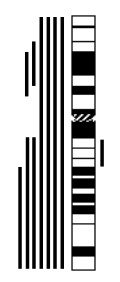

11

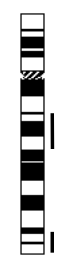

12

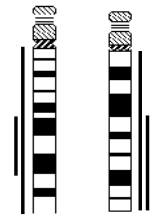

13

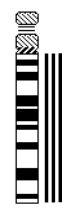

15

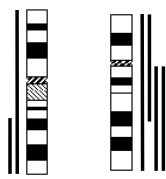

17

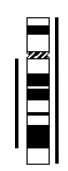

18
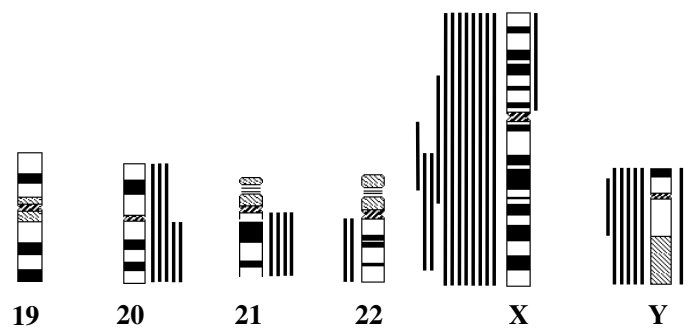

\section{Malignant insulinomas $(\mathbf{n}=18)$}

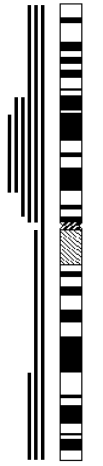

1

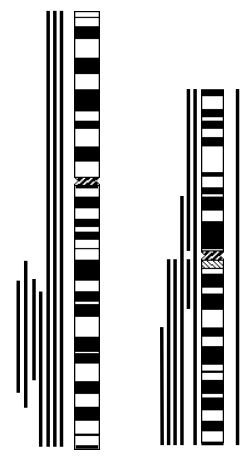

3

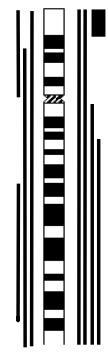

4

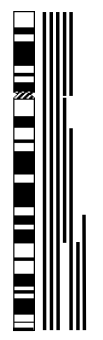

5

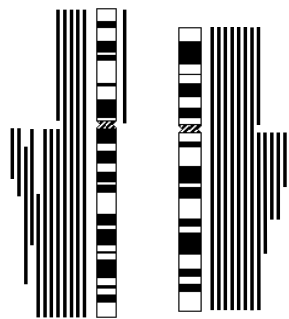

7
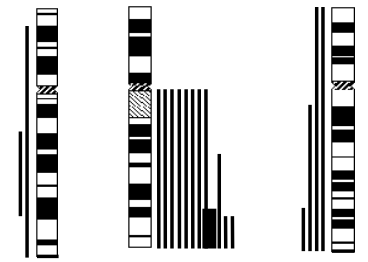

9

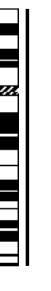

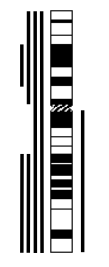

11

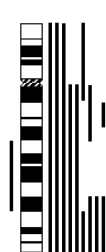

12

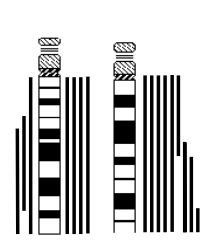

1314

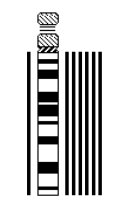

15

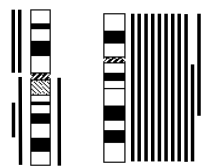

$16 \quad 17$

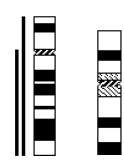

18
20

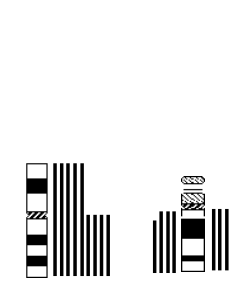

21

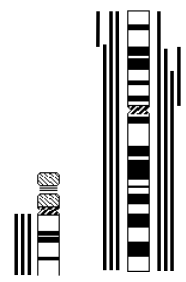

22 X

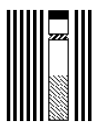

$\mathbf{Y}$

Figure 1 Summary of all DNA copy number changes detected by CGH in 44 benign and 18 malignant insulinomas. Vertical lines on the left of the chromosome ideograms indicate the number of cases showing losses of the corresponding chromosomal regions; vertical lines on the right indicate the number of cases showing gains. The bold lines represent amplifications at $4 \mathrm{pr} 6$ and 9q34. Gains on 1p32-pter, 16p, 19, and 22 were not analyzed (see text). 
Endocrine-Related Cancer (2005) 12 435-447

Table 2 Double-target FISH results in 14 benign (cases 1-14) and one malignant (case 15) insulinomas

\begin{tabular}{|c|c|c|c|c|c|c|}
\hline Tumor & CGH chr 6 & $6 C: 6 q 21^{a}$ & CGH chr 9 & $9 C: 9 q 34^{a}$ & CGH chr 11 & $11 C: 11 q 13^{a}$ \\
\hline 1 & 0 & $2: 2$ & 0 & $2: 2$ & $11 p q^{-}$ & $1: 1$ \\
\hline 2 & 0 & $2: 2$ & 0 & $2: 2$ & 0 & $2: 1(26 \%)$ \\
\hline 3 & 0 & $2: 2$ & 0 & $2: 2$ & 0 & $2: 2$ \\
\hline 4 & 0 & $2: 2$ & 0 & $2: 2$ & 0 & $2: 2$ \\
\hline 5 & 0 & $2: 2$ & 0 & $2: 2(41 \%), 3: 3(30 \%)$ & 0 & $2: 2$ \\
\hline 6 & 0 & $2: 2$ & 0 & $2: 2,2:>2(27 \%)$ & 0 & $2: 2$ \\
\hline 7 & 0 & $2: 2$ & 0 & $2: 2$ & 0 & $2: 2$ \\
\hline 8 & 0 & $2: 2$ & $9 \mathrm{qrg}^{+}$ & $2: 3$ & 0 & $2: 2$ \\
\hline 9 & 0 & $2: 2$ & $9 q 34^{+}$ & $3: 3$ & 0 & $2: 2$ \\
\hline \multirow[t]{2}{*}{10} & 0 & $2: 2$ & $9 p q^{+}$ & Area $1: 3: 3$ & $11 q 13^{+}$ & $2: 3$ \\
\hline & & & $9 q 34^{+}$ & Area $2: 3: 5,3:>5($ Amp) & & \\
\hline 11 & 0 & $3: 3$ & $9 q 34^{+}$ & $3: 3(37 \%), 4: 4(37 \%)$ & 0 & $2: 2$ \\
\hline 12 & 0 & $3: 3$ & $9 q 32-34^{+}$ & $3: 3(42 \%), 3: 4(24 \%)$ & $11 p q^{-}$ & $2: 2$ \\
\hline 13 & 0 & $3: 3$ & $9 q 34^{+}$ & $3: 6$ & 0 & $3: 3$ \\
\hline 14 & $6 \mathrm{pq}^{+}$ & $3: 3$ & 0 & $2: 2$ & 0 & $2: 1(20 \%)$ \\
\hline \multirow[t]{2}{*}{15} & $6 q^{-}$ & $2: 1(34 \%)$ & $9 q^{+}$ & $4: 4(44 \%), 4: 8(25 \%)$ & 0 & $2: 1(22 \%)$ \\
\hline & & & $9 q 34^{++}$ & $2: 12(5 \% ; A m p)$ & & \\
\hline
\end{tabular}

${ }^{a}$ FISH results: $2-1$ ( $\left.n \%\right), 2$ copies of the centromere probe and 1 copy of the locus-specific probe in $n \%$ of nuclei (in the case of subpopulation of cells); Amp, amplification.

$7 \mathrm{q}, 12 \mathrm{q}, 14 \mathrm{q}, 17 \mathrm{pq}$ and $21 \mathrm{q}$ were also significantly correlated with a tumor size $\geq 2 \mathrm{~cm}$ (Table $3 \mathrm{~A}$ ).

Another indicator of risk of malignancy is a proliferation index of $\geq 2 \%$ measured by immunohistochemistry of Ki67 (MIB-1 monoclonal antibody). Comparison of 22 benign and 13 malignant insulinomas revealed only one benign and four malignant insulinomas showing a proliferation index $\geq 2 \%$. This finding did not reach statistical significance when comparing benign and malignant tumors. Gain of chromosome $12 \mathrm{q}$ was the only parameter significantly correlated with a proliferative rate of $\geq 2 \%$ (60 vs $13 \%$ in the group with a proliferation index $<2 \%$ respectively, $P=0.044$ ).

Table 4 shows these parameters as markers in univariate and bivariate analysis with the percentages of correctly classified tumors (sensitivity and specificity) and their odds ratios. The best classification markers for malignant behavior according to sensitivity in univariate analysis are the total number of aberrations $(\geq 8)$, gains $(\geq 5)$ and the size of the tumor ( $\geq 2 \mathrm{~cm}$ in diameter). A combination of the total number of gains $(\geq 5)$ and losses $(\geq 5)$ provides an even better sensitivity as shown by bivariate analysis with two independent markers.

\section{MEN1 mutation analysis}

MEN1 mutation analysis was performed on 43 sporadic insulinomas from which sufficient DNA was available. Only one insulinoma (male, 42 years old) showed a somatic $7 \mathrm{bp}$ deletion in exon 10 (position
1527) of the MEN1 gene, as shown in Fig. 2D-F. CGH analysis of this benign tumor showed gains of $5 \mathrm{pq}, 6 \mathrm{pq}$ and 21q. Although loss of chromosome 11q was not identified by CGH, FISH analysis revealed loss of the MEN1 gene in $20 \%$ of cells (see above and Table 2, patient 14) suggesting deletion of the wildtype locus. A known polymorphism in exon 2 (S145S) was found in an additional tumor.

\section{Discussion}

We have performed a comprehensive genome-wide survey of DNA copy number changes in a series of 62 human sporadic insulinomas with the goal to identify genetic alterations that discriminate benign tumors from cases with metastatic progression. Particularly the CGH detection of a high number of confined chromosomal alterations per tumor was found to strongly correlate with metastatic disease in this EPT subtype. In addition, this study provides further evidence that gain and/or amplification of chromosome 9q, rather than MEN1 mutations, is a frequent event in sporadic insulinomas that may be of pathogenetic importance.

Our data strongly indicate that insulinoma progression is driven by the accumulation of genetic changes, as is also known to occur in other types of human carcinomas (Nowak et al. 2002, Draviam et al. 2004, Vogelstein \& Kinzler 2004). A marked distinction between benign and malignant insulinomas can be made on the basis of the number of genomic 

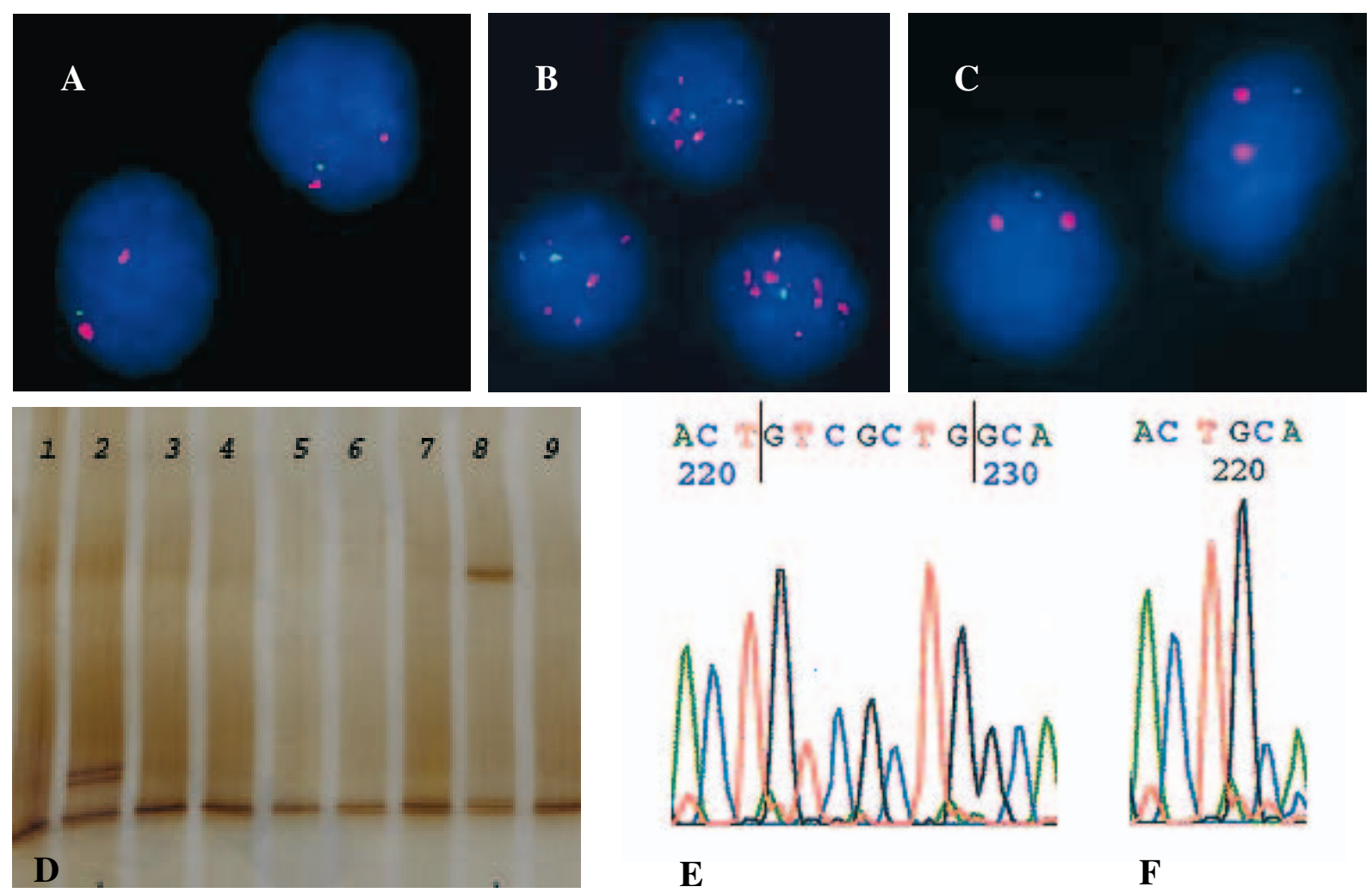

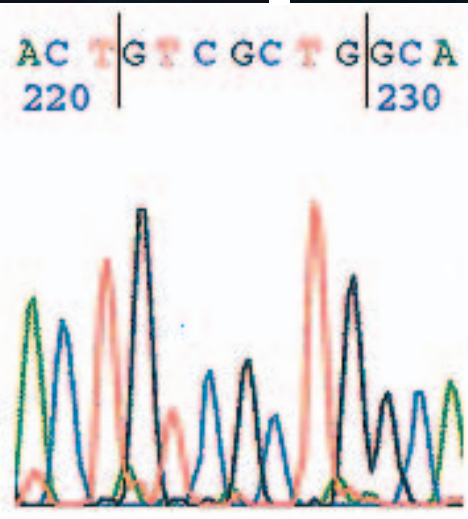

$\mathbf{E}$

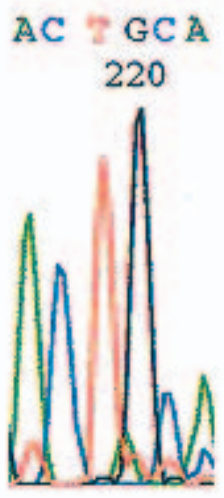

F

Figure 2 Results of representative examples of insulinoma cases examined by FISH (see Table 3) and MEN1 mutation analysis. (A) Loss of 6 q21 (green; arrow) with respect to centromere 6 (red) in patient 15. (B) Gain and amplification of 9q34 (red) with respect to centromere 9 (green; arrow) in patient 10. (C) Loss of 11 q13 (green; arrow) with respect to centromere 11 (red) in patient 2. (D) SSCP analysis of exon 10 of the MEN1 gene in seven tumors with a negative control (lane 1) and a positive control (lane 2). Lane 8 represents DNA from patient 14 (Table 3) harboring a MEN1 mutation. (E) The normal MEN1 sequence profile of exon 10, with the part deleted in $(F)$ between the vertical lines. $(F)$ Sequence profile of patient 14 with the MEN1 mutation, a $7 \mathrm{bp}$ deletion (GTCGCTG) in exon 10.

alterations per tumor as identified by CGH. The most prominent DNA copy number changes enabling this differentiation include loss of chromosome 6q (SRI $6 q 14$ and $6 q 21-22$ ) and gains of 7q, 12q (SRI 12q24), $14 \mathrm{q}$ and $17 \mathrm{pq}$. In comparison with currently used indicators of malignancy, including tumor size $>2 \mathrm{~cm}$ and proliferative index $\geq 2 \%$, high numbers of chromosomal alterations are significantly more powerful for this purpose (Table 4). The most potential indicators for metastatic progression detected in our study include: (i) a combination of gains and losses (both $\geq 5$ per tumor), (ii) the total number of aberrations ( $\geq 8$ per tumor), (iii) a combination of losses $(\geq 5$ per tumor) and 17q gain, and (iv) the total number of gains ( $\geq 5$ per tumor). Thus, our data suggest that chromosomal instability (CIN), an abnormal cell state with elevated chromosomal gains and losses, is the optimal predictor for malignant progression in sporadic insulinomas. It will be interesting to identify the target genes that might be involved in the development of CIN (Draviam et al. 2004).

The identified chromosomal regions altered in insulinomas point to loci containing putative oncogenes and tumor suppressor genes. The most frequent aberration identified by CGH in about $60 \%$ of both benign and malignant insulinomas is the increase of chromosome $9 \mathrm{q}$ copy numbers. This extends our previous findings in a small group of benign insulinomas and endorses the importance of this genetic event in early tumor development (Speel et al. 2001). Moreover, insulinomas with $9 \mathrm{q}$ gain harbored a significantly higher number of aberrations, especially gains, than the remaining tumors, and this difference in genetic makeup suggests the evolution along two different genetic pathways in insulinoma development. The SRI is located at $9 \mathrm{q} 34$ and this region was found amplified in two insulinomas. Gain and/or amplification of this region have been reported in other 
Table 3 Parameters associated with malignancy and tumor size (A) or 9q gain (B)

\begin{tabular}{|c|c|c|c|c|c|c|}
\hline & Benign $(n=44)$ & Malignant $(n=18)$ & $\boldsymbol{P}$ & Size $<2 \mathrm{~cm}(n=40)$ & Size $\geq 2 \mathrm{~cm}(n=22)$ & $\boldsymbol{P}$ \\
\hline Total aberrations & $4.2 \pm 4.6$ & $14.1 \pm 6.7$ & $<0.0001^{\mathrm{a}}$ & $4.7 \pm 4.8$ & $11.9 \pm 8.0$ & $<0.0001^{a}$ \\
\hline Losses & $1.7 \pm 2.5$ & $5.7 \pm 4.5$ & $<0.0001^{a}$ & $1.7 \pm 2.5$ & $5.0 \pm 4.5$ & $<0.0001^{\mathrm{a}}$ \\
\hline Gains & $2.5 \pm 3.3$ & $7.3 \pm 4.4$ & $<0.0001^{a}$ & $2.8 \pm 3.1$ & $6.1 \pm 5.2$ & $<0.0001^{a}$ \\
\hline Mean size $(\mathrm{cm})$ & $1.5 \pm 0.5$ & $3.8 \pm 2.3$ & $<0.0001^{a}$ & - & - & - \\
\hline $2 q$ loss & $5 \%$ & $39 \%$ & $0.002^{c}$ & $8 \%$ & $27 \%$ & $N S^{b}$ \\
\hline $3 q$ loss & $0 \%$ & $33 \%$ & $<0.0001^{\mathrm{c}}$ & $3 \%$ & $23 \%$ & $0.010^{\mathrm{b}}$ \\
\hline $4 q$ gain & $0 \%$ & $22 \%$ & $0.005^{c}$ & $0 \%$ & $18 \%$ & $0.025^{\mathrm{b}}$ \\
\hline $5 p$ gain & $11 \%$ & $28 \%$ & $N S^{c}$ & $8 \%$ & $32 \%$ & $0.033^{b}$ \\
\hline $5 q$ gain & $16 \%$ & $39 \%$ & $\mathrm{NS}^{\mathrm{c}}$ & $13 \%$ & $41 \%$ & $0.025^{\mathrm{b}}$ \\
\hline $6 p$ loss & $0 \%$ & $28 \%$ & $0.001^{c}$ & $0 \%$ & $23 \%$ & $0.008^{b}$ \\
\hline $6 q$ loss & $0 \%$ & $67 \%$ & $<0.0001^{\mathrm{c}}$ & $5 \%$ & $45 \%$ & $<0.0001^{\mathrm{b}}$ \\
\hline $7 q$ gain & $18 \%$ & $67 \%$ & $0.001^{c}$ & $20 \%$ & $55 \%$ & $0.012^{b}$ \\
\hline $10 q$ loss & $0 \%$ & $22 \%$ & $0.005^{c}$ & $0 \%$ & $18 \%$ & $0.025^{\mathrm{b}}$ \\
\hline $12 p$ gain & $0 \%$ & $22 \%$ & $0.005^{c}$ & $0 \%$ & $18 \%$ & $0.025^{\mathrm{b}}$ \\
\hline $12 q$ gain & $2 \%$ & $50 \%$ & $<0.0001^{\mathrm{c}}$ & $8 \%$ & $32 \%$ & $0.033^{b}$ \\
\hline $14 q$ gain & $5 \%$ & $50 \%$ & $<0.0001^{\mathrm{c}}$ & $5 \%$ & $41 \%$ & $0.001^{b}$ \\
\hline $15 q$ gain & $7 \%$ & $33 \%$ & $0.014^{\mathrm{c}}$ & $8 \%$ & $27 \%$ & $N S^{b}$ \\
\hline $17 p$ gain & $5 \%$ & $56 \%$ & $<0.0001^{\mathrm{c}}$ & $10 \%$ & $36 \%$ & $0.029^{b}$ \\
\hline $17 q$ gain & $9 \%$ & $61 \%$ & $<0.0001^{\mathrm{c}}$ & $13 \%$ & $45 \%$ & $0.010^{b}$ \\
\hline $20 p$ gain & $7 \%$ & $28 \%$ & $0.039^{c}$ & $8 \%$ & $23 \%$ & $N S^{b}$ \\
\hline $20 q$ gain & $11 \%$ & $50 \%$ & $0.002^{c}$ & $18 \%$ & $32 \%$ & $N S^{b}$ \\
\hline $21 q$ gain & $9 \%$ & $17 \%$ & $\mathrm{NS}^{\mathrm{C}}$ & $3 \%$ & $27 \%$ & $0.011^{\mathrm{b}}$ \\
\hline $22 q$ loss & $5 \%$ & $22 \%$ & $N S^{c}$ & $3 \%$ & $23 \%$ & $0.033^{b}$ \\
\hline
\end{tabular}

B

\begin{tabular}{|c|c|c|c|c|c|c|c|}
\hline \multirow[b]{2}{*}{ Parameter } & \multicolumn{3}{|c|}{ Insulinomas with 9q gain } & \multirow[b]{2}{*}{ Parameter } & \multicolumn{3}{|c|}{ Insulinomas without $9 \mathrm{q}$ gain } \\
\hline & Benign $(n=25)$ & Malignant $(n=11)$ & $\boldsymbol{P}$ & & Benign $(n=19)$ & Malignant $(n=7)$ & $\boldsymbol{P}$ \\
\hline \multicolumn{8}{|c|}{ Common parameters } \\
\hline $6 q$ loss & $0 \%$ & $64 \%$ & $<0.0001^{\mathrm{c}}$ & $6 q$ loss & $0 \%$ & $71 \%$ & $<0.0001^{\mathrm{c}}$ \\
\hline $7 q$ gain & $32 \%$ & $73 \%$ & $0.034^{\mathrm{C}}$ & $7 q$ gain & $0 \%$ & $57 \%$ & $0.002^{c}$ \\
\hline $14 q$ gain & $8 \%$ & $45 \%$ & $0.018^{\mathrm{c}}$ & $14 q$ gain & $0 \%$ & $57 \%$ & $0.002^{\mathrm{C}}$ \\
\hline $17 q$ gain & $16 \%$ & $73 \%$ & $0.002^{\mathrm{c}}$ & $17 q$ gain & $0 \%$ & $43 \%$ & $0.013^{\mathrm{C}}$ \\
\hline \multicolumn{8}{|c|}{ Group-specific parameters } \\
\hline $12 p$ gain & $0 \%$ & $27 \%$ & $0.023^{\mathrm{c}}$ & $1 p$ loss & $5 \%$ & $57 \%$ & $0.010^{c}$ \\
\hline $12 q$ gain & $4 \%$ & $64 \%$ & $<0.0001^{\mathrm{c}}$ & $2 q$ loss & $0 \%$ & $43 \%$ & $0.013^{c}$ \\
\hline $13 q$ gain & $0 \%$ & $27 \%$ & $0.023^{c}$ & $3 q$ loss & $0 \%$ & $57 \%$ & $0.002^{\mathrm{C}}$ \\
\hline $17 p$ gain & $8 \%$ & $73 \%$ & $<0.0001^{\mathrm{c}}$ & $6 p$ loss & $0 \%$ & $57 \%$ & $0.002^{\mathrm{C}}$ \\
\hline \multirow[t]{4}{*}{$20 q$ gain } & $20 \%$ & $64 \%$ & $0.020^{c}$ & $21 q$ loss & $0 \%$ & $43 \%$ & $0.013^{c}$ \\
\hline & & & & $22 q$ loss & $5 \%$ & $57 \%$ & $0.010^{c}$ \\
\hline & & & & Y loss & $5 \%$ & $57 \%$ & $0.010^{c}$ \\
\hline & & & & $5 q$ gain & $5 \%$ & $57 \%$ & $0.010^{c}$ \\
\hline
\end{tabular}

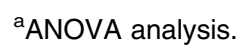

${ }^{\mathrm{b}}$ chi-square test.

${ }^{\mathrm{c}}$ Fisher exact test.

$\mathrm{NS}=$ not significant.

neoplasms, including neuroendocrine tumors (Dannenberg et al. 2000, Figueiredo et al. 2000, Garcia et al. 2002), schwannomas (Warren et al. 2003), and enteropathy-type T-cell lymphomas (Baumgärtner et al. 2003). There are several candidate genes localized in this region, i.e. the oncogene $V A V 2$ (Booden et al.
2002), CDK9, a co-regulator of the progression through the cell cycle (Napolitana et al. 2002), Notch-1, a transmembrane receptor promoting differentiation of T-cells (Aster et al. 2000), LMX1B, a LIMhomeodomain-containing protein involved in a variety of developmental events (Hobert \& Westphall 2000), 
Table 4 Parameters for assessing malignant behavior

\begin{tabular}{|c|c|c|c|}
\hline Parameter & Specificity $^{\mathrm{a}}$ & Sensitivity $^{\mathrm{b}}$ & OR (95\% Cl) \\
\hline \multicolumn{4}{|l|}{ Univariate analysis } \\
\hline Total no. of aberrations $\geq 8$ & 82 & 83 & $22.5(5.2-96.6)$ \\
\hline Total no. of gains $\geq 5$ & 89 & 78 & $27.3(6.4-116.3)$ \\
\hline Total no. of losses $\geq 5$ & 89 & 50 & $7.8(2.1-29.0)$ \\
\hline $6 q$ loss & 100 & 67 & $>86(9.4-785.2)$ \\
\hline $14 q$ gain & 95 & 50 & $21(3.9-114.1)$ \\
\hline $17 q$ gain & 91 & 61 & $15.7(3.9-63.6)$ \\
\hline Size $\geq 2 \mathrm{~cm}$ & 82 & 76 & $15.8(4.1-60.7)$ \\
\hline Proliferative index (Ki67) $\geq 2 \%$ & 95 & 31 & $9.3(0.9-95.6)$ \\
\hline \multicolumn{4}{|l|}{ Bivariate analysis } \\
\hline Total no. of gains $\geq 5$, and total no. of losses $\geq 5$ & 77 & 89 & $20.9(4.5-96.0)$ \\
\hline $17 q$ gain, and total no. of losses $\geq 5$ & 80 & 83 & $15.8(4.0-61.6)$ \\
\hline
\end{tabular}

$\mathrm{OR}=$ odds ratio, $95 \% \mathrm{Cl}=95 \%$ confidence interval.

apercent of benign tumors without the parameter.

${ }^{\mathrm{b}}$ Percent of malignant insulinomas with the parameter.

$T S C 1$, the tuberous sclerosis gene 1 , and $c A b l$, playing a role in chronic myeloid leukemia (Goldman \& Melo 2003). In TSC patients, insulinomas are occasionally detected. In these tumors, mutations in TSC1 or TSC2 (at 16p13.3) in combination with loss of the wildtype allele result in stimulation of cell growth and proliferation via dysregulation of mTOR activity (Davoren \& Epstein 1992, Yong et al. 2004). In our series of insulinomas we noticed often $\geq 3$ copies of $9 \mathrm{q} 34$ instead of loss. The intriguing finding that duplication/ amplification of mutated alleles may also lead to tumorigenesis (Zhuang et al. 1998) should be examined in this respect. The oncogenic significance of the $c A b l$ gene in insulinomas is unknown, although we identified two cases with amplification of this locus by FISH analysis, and $c A b l$ overexpression has been reported in two rat insulinoma cell lines (DeAizpurua et al. 1997). Additional research is needed to clarify its possible role in the development of insulinomas.

Despite the importance of $M E N 1$ gene mutations in EPTs, we only identified one case with a MEN1 mutation in a group of 43 insulinomas. In this tumor the wildtype allele was also lost. This finding is in agreement with other studies suggesting a minor role for MEN1 in human insulinomas (Zhuang et al. 1997, Görtz et al. 1999, Cupisti et al. 2000, Gumbs et al. 2002, Moore et al. 2003). However, other mechanisms of gene inactivation may be involved in insulinoma development. Promoter hypermethylation of the MEN1 gene has not been detected so far (Chan et al. 2003). The many different candidate proteins found to interact with menin may also implicate that other mechanisms can lead to down-regulation of the MEN1 protein (Chandrasekharappa \& Teh 2003). This needs to be further investigated using, for example, RT-PCR or immunohistochemistry (Cavallari et al. 2003). The high frequency of loss of heterozygosity in EPTs, including insulinomas, may also point to additional tumor suppressor gene loci at 11q (Chakrabarti et al. 1998, Speel et al. 2002).

Chromosome $6 \mathrm{q}$ loss proved to be the strongest chromosome-specific marker to classify the metastatic potential of insulinomas, because it was only detected in the malignant tumors. This is in agreement with a previous study, in which we mapped the SRI to 6q22-24 in sporadic EPTs in general (Barghorn et al. $2001 b$ ). Several candidate tumor suppressor genes are located in the common region of deletion, including AIM1 (absent in melanoma 1), a beta-gammacrystallin superfamily member inhibiting cellular growth by possible interactions with the cytoskeleton (Ray et al. 1997), CCNC (cyclin C) (Polly et al. 2000), PTPRK (receptor-type protein-tyrosine phosphatase kappa), possibly involved in the regulation of cell contact and adhesion via dephosphorylation of catenins or cadherins (Yang et al. 1996), CX43 (connexin 43), a gap junction protein involved in intercellular communication (Mesnil 2002), and LOT1 (PLAGL1/ZAC1). LOT1 is a zinc-finger nuclear transcription factor that regulates the type 1 receptor for pituitary adenylate cyclase-activating polypeptide, an important mediator of autocrine control of insulin secretion in the pancreatic islet. Furthermore, it possesses anti-proliferative effects and appears to be epigenetically silenced in different types of cancer, including parathyroid adenomas (Pagotto et al. 2000, Abdollahi et al. 2003). Future studies will determine if these genes are involved in insulinoma oncogenesis. 
Deletions of other chromosomal regions that were reported to be associated with malignant behavior of EPTs, such as 1p, 3p, 3q, 11q, 17p, 22q and X (Chung et al. 1997, 1998, Beghelli et al. 1998, Ebrahimi et al. 1999, Hessman et al. 1999, Barghorn et al. 2001a,b, Guo et al. 2002, Missiaglia et al. 2002, Wild et al. 2002), were only occasionally observed in this CGH study on insulinomas. Losses of chromosome $3 p$ and $3 q$ were identified significantly more frequently in the malignant insulinomas, but only at low frequencies of 17 and $33 \%$ respectively. This holds also true for the association of $1 p$ and $22 q$ losses with malignancy in the group of insulinomas without $9 \mathrm{q}$ gain. These results indicate that the reported alterations are infrequent in insulinomas. However, it cannot be excluded that small deletions and gains are missed by $\mathrm{CGH}$ analysis due to the resolution of $\sim 5-10 \mathrm{Mb}$. This might also underscore to some extent the frequency of alterations yet identified in this study. Gains of chromosomes 7pq, $12 \mathrm{q}, 14 \mathrm{q}$ and $17 \mathrm{pq}$ have been frequently reported in many types of cancer and are also commonly observed in sporadic gastrointestinal neuroendocrine tumors, including EPTs (Knuutila et al. 1998, Terris et al. 1998, Stumpf et al. 2000, Tönnies et al. 2001, Zhao et al. 2001). However, so far no convincing evidence has been presented of specific genes on these chromosomes playing a role in EPTs in general or insulinomas in particular (Speel et al. 1999, Goebel et al. 2002).

In summary, our data show that benign insulinomas can be efficiently distinguished from tumors with metastatic progression on the basis of the chromosomal profile of the tumors. Furthermore, because these alterations are recurrently detected by $\mathrm{CGH}$, the identified chromosomal regions may harbor candidate cancer genes that are important in insulinoma pathogenesis. Whereas the presence of $9 \mathrm{q}$ gain and/or amplification appears to be an important genetic event in insulinoma development, the MEN1 gene is unlikely to be involved in this process.

\section{Acknowledgements}

We thank V M Cuijpers (Department of Pathology, UMC Nijmegen, The Netherlands), M Verdaasdonk (Department of Pathology, UMC Utrecht, The Netherlands) and $\mathrm{T}$ Locher (Department of Pathology, University Hospital Zurich, Switzerland) for expert technical assistance, and $\mathrm{P} \mathrm{U}$ Heitz and $\mathrm{J}$ Roth (Department of Pathology, University Hospital Zurich, Switzerland), A H N Hopman (Department of Molecular Cell Biology, University of Maastricht, The Netherlands) and A C Voogd (Department of Epidemiology, University of Maastricht, The
Netherlands) for helpful discussions. This study was supported by The Netherlands Foundations Vanderes and Sacha Swarttouw-Hijmans, and the Association for International Cancer Research (AICR), St Andrews, UK and in part by the National Science Foundation (31-618845.0) and Swiss Cancer Research Foundation (997-02-2000). We declare that there is no conflict of interest that would prejudice its impartiality.

\section{References}

Abdollahi A, Pisarcik D, Roberts D, Weinstein J, Cairns P \& Hamilton TC 2003 LOT1 (PLAGL1/ZAC1), the candidate tumor suppressor gene at chromosome 6q24-25, is epigenetically regulated in cancer. Journal of Biological Chemistry 278 6041-6049.

Aster JC, Xu L, Karnell FG, Patriub V, Pui JC \& Pear WS 2000 Essential roles for ankyrin repeat and transactivation domains in induction of T-cell leukemia by Notch-1. Molecular and Cellular Biology 20 7505-7515.

Barghorn A, Komminoth P, Bachmann D, Rütimann K, Saremaslani P, Mulatta-Feurer S, Perren A, Roth J, Heitz PU \& Speel EJM 2001a Deletion at 3p25.3-p23 is frequently encountered in endocrine pancreatic tumours and is associated with metastatic progression. Journal of Pathology 194 451-458.

Barghorn A, Speel EJM, Farspour B, Saremaslani P, Schmid S, Perren A, Roth J, Heitz PU \& Komminoth P $2001 b$ Putative tumor suppressor loci at 6q22 and 6q23q24 are involved in the malignant progression of sporadic endocrine pancreatic tumors. American Journal of Pathology 158 1903-1911.

Baumgärtner AK, Zettl A, Chott A, Ott G, Müller-Hermelink HK \& Starostik P 2003 High frequency of genetic aberrations in enteropathy-type T-cell lymphoma. Laboratory Investigation 83 1509-1516.

Beghelli S, Pelosi G, Zamboni G, Falconi M, Iacono C, Bordi C \& Scarpa A 1998 Pancreatic endocrine tumours: evidence for a tumour suppressor pathogenesis and for a tumour suppressor gene on chromosome $17 \mathrm{p}$. Journal of Pathology 186 41-50.

Bertolino P, Tong WM, Herrera PL, Casse H, Zhang CX \& Wang ZQ 2003 Pancreatic $\beta$-cell-specific ablation of the multiple endocrine neoplasia type 1 (MEN1) gene causes full penetrance of insulinoma development in mice. Cancer Research 63 4836-4841.

Booden MA, Campbell SL \& Der CJ 2002 Critical but distinct roles for the pleckstrin homology and cysteinerich domains as positive modulators of Vav2 signaling and transformation. Molecular and Cellular Biology 22 2487-2497.

Böttger T, Seidl C, Seifert JK, Heintz A, Bretz B \& Junginger T 1997 Value of quantitative DNA analysis in endocrine tumors of the pancreas. Oncology 54 318-323.

Cavallari I, D'agostino DM, Ferro T, Rosato A, Barzon L, Pasquali C, Fogar P, Theodoropoulou M, Esposito G \& Boscaro M 2003 In situ analysis of human menin in normal 
and neoplastic pancreatic tissues: evidence for differential expression in exocrine and endocrine cells. Journal of Clinical Endocrinology and Metabolism 88 3893-3901.

Chakrabarti R, Srivatsan ES, Wood TF, Eubanks PJ, Ebrahimi SA, Gatti RA, Passaro E Jr \& Sawicki MP 1998 Deletion mapping of endocrine tumors localizes a second tumor suppressor gene on chromosome band 11q13. Genes, Chromosomes and Cancer 22 130-137.

Chan AO, Kim SG, Bedeir A, Issa JP, Hamilton SR \& Rashid A 2003 CpG island methylation in carcinoid and pancreatic endocrine tumors. Oncogene 22 924-934.

Chandrasekharappa SC \& Teh BT 2003 Functional studies of the MEN1 gene. Journal of Internal Medicine $\mathbf{2 5 3}$ 606-615.

Chun J \& Doherty GM 2001 Pancreatic endocrine tumors. Current Opinion in Oncology 13 52-56.

Chung DC, Smith AP, Louis DN, Graeme-Cook F, Warshaw AL \& Arnold AA 1997 Novel pancreatic endocrine tumor suppressor gene locus on chromosome $3 \mathrm{p}$ with clinical prognostic implications. Journal of Clinical Investigation $100404-410$.

Chung DC, Brown SB, Graeme-Cook F, Tillotson LG, Warshaw AL, Jensen RT \& Arnold A 1998 Localisation of putative tumor suppressor loci by genome-wide allelotyping in human pancreatic endocrine tumors. Cancer Research 58 3706-3711.

Cupisti K, Höppner W, Dotzenrath C, Simon D, Berndt I, Röher HD \& Goretzki PE 2000 Lack of MEN1 gene mutations in 27 sporadic insulinomas. European Journal of Clinical Investigation 30 325-329.

Dannenberg H, Speel EJ, Zhao J, Saremaslani P, van der Harst E, Roth J, Heitz PU, Bonjer HJ, Dinjens WN, Mooi MJ et al. 2000 Losses of chromosome $1 \mathrm{p}$ and $3 \mathrm{q}$ are early genetic events in the development of sporadic pheochromocytomas. American Journal of Pathology 157 353-359.

Davoren PM \& Epstein MT 1992 Insulinoma complicating tuberous sclerosis. Journal of Neurology, Neurosurgery and Psychiatry 55 1209-1212.

DeAizpurua HJ, Cram DS, Naselli G, Devereux L \& Dorow DS 1997 Expression of mixed lineage kinase-1 in pancreatic $\beta$-cell lines at different stages of maturation and during embryonic pancreas development. Journal of Biological Chemistry 272 16364-16373.

Draviam VM, Xie S \& Sorger PK 2004 Chromosome segregation and genomic stability. Current Opinion in Genetics and Development 14 120-125.

Ebrahimi SA, Wang EH, Wu A, Schreck RR, Passaro E Jr \& Sawicki MP 1999 Deletion of chromosome 1 predicts prognosis in pancreatic endocrine tumors. Cancer Research 59 311-315.

Figueiredo BC, Ribeiro RC, Zambetti G, Haddad B, Pianovsky MD, Pereira RM, DeLacerda L \& Sandrini R 2000 Amplification of 9q34 in childhood adrenocortical tumors: a specific feature unrelated to ethnic origin or living conditions. Brazilian Journal of Medical and Biological Research 33 1217-1224.
Garcia JL, Tardio JC, Gutierrez NC, Gonzalez MB, Polo JR, Hernandez JM \& Menarguez J 2002 Chromosomal imbalances identified by comparative genomic hybridization in sporadic parathyroid adenomas. European Journal of Endocrinology 146 209-213.

Goebel SU, Iwamoto M, Raffeld M, Gibril F, Hou W, Serrano J \& Jensen RT 2002 HER-2/neu expression and gene amplification in gastrinomas: correlations with tumor biology, growth, and aggressiveness. Cancer Research 62 3702-3710.

Goldman JM \& Melo JV 2003 Chronic myeloid leukemiaadvances in biology and new approaches to treatment. New England Journal of Medicine 349 1451-1464.

Görtz B, Roth J, Krähenmann A, De Krijger RR, Muletta-Feurer S, Rütimann K, Saremaslani P, Speel EJM, Heitz PU \& Komminoth P 1999 Mutations and allelic deletions of the MEN 1 gene are associated with a subset of sporadic endocrine pancreatic and neuroendocrine tumors and not restricted to foregut neoplasms. American Journal of Pathology 154 429-436.

Graeme-Cook F, Bell DA, Flotte TJ, Preffer F, Pastel-Levy C, Nardi G \& Compton C 1990 Aneuploidy in pancreatic insulinomas does not predict malignancy. Cancer $\mathbf{6 6}$ 2365-2368.

Gumbs AA, Moore PS, Falconi M, Bassi C, Beghelli S, Modlin I \& Scarpa A 2002 Review of the clinical, histological, and molecular aspects of pancreatic endocrine neoplasms. Journal of Surgical Oncology 81 45-53.

Guo SS, Arora C, Shimoide AT \& Sawicki MP 2002 Frequent deletion of chromosome 3 in malignant sporadic pancreatic endocrine tumors. Molecular and Cellular Endocrinology 190 109-114.

Hessman O, Lindberg D, Einarsson A, Lillhager P, Carling T, Grimelius L, Eriksson B, Akerström G, Westin G \& Skogseid B 1999 Genetic alterations on 3p, 11q13, and $18 \mathrm{q}$ in nonfamilial and MEN1-associated pancreatic endocrine tumors. Genes, Chromosomes and Cancer 26 258-264.

Hobert O \& Westphall H 2000 Functions of LIM-homeobox genes. Trends in Genetics 16 75-83.

Hochwald SN, Zee S, Conlon KC, Colleoni R, Louie O, Brennan MF \& Klimstra DS 2002 Prognostic factors in pancreatic endocrine neoplasms: an analysis of 136 cases with a proposal for low-grade and intermediate-grade groups. Journal of Clinical Oncology 20 2633-2642.

Knuutila S, Björkqvist AM, Autio K, Tarkkanen M, Wolf M, Monni O, Szymanska J, Larramendy ML, Tapper J, Pere H et al. 1998 DNA copy number amplifications in human neoplasms: review of comparative genomic hybridization studies. American Journal of Pathology 152 1107-1123.

Komminoth P, Perren A, Öberg K, Rindi G, Heitz PU \& Klöppel G 2004 Insulinoma. In Pathology and Genetics. Tumours of Endocrine Organs, pp 183-186. Eds RA DeLellis, RV Lloyd, PU Heitz \& C Eng. Lyon: IARC Press. 
Leothela PD, Jauch A, Holtgreve-Grez H \& Thakker RV 2003 Genetics of neuroendocrine and carcinoid tumours. Endocrine-Related Cancer 10 437-450.

Mesnil M 2002 Connexins and cancer. Biology of the Cell 94 493-500.

Missiaglia E, Moore PS, Williamson J, Lemoine NR, Falconi M, Zamboni G \& Scarpa A 2002 Sex chromosome anomalies in pancreatic endocrine tumors. International Journal of Cancer 98 532-538.

Moore PS, Beghelli S, Zamboni G \& Scarpa A 2003 Genetic abnormalities in pancreatic cancer. Molecular Cancer $\mathbf{2}$ $7-12$.

Napolitana G, Majello B \& Lania L 2002 Role of cyclin/ $\mathrm{Cdk} 9$ complex in basal and regulated transcription (review). International Journal of Oncology 21 171-177.

Nowak MA, Komarova NL, Sengupta A, Jallepalli PV, Shih LM, Vogelstein B \& Lengauer C 2002 The role of chromosomal instability in tumor initiation. PNAS 99 16226-16231.

Pagotto U, Arzberger T, Theodoropoulou M, Grubler Y, Pantaloni C, Saeger W, Losa M, Journot L, Stalla GK \& Spengler D 2000 The expression of the antiproliferative gene ZAC is lost or highly reduced in non-functioning pituitary adenomas. Cancer Research $606794-6799$.

Perren A, Barghorn A, Schmid S, Saremaslani P, Roth J, Heitz PU \& Komminoth P 2002 Absence of somatic SDHD mutations in sporadic neuroendocrine tumors and detection of two germline variants in paraganglioma patients. Oncogene 21 7605-7608.

Polly P, Danielsson C, Schrader M \& Carlberg C 2000 Cyclin $\mathrm{C}$ is a primary 1alpha,25-dihydroxyvitamin $\mathrm{D}(3)$ responding gene. Journal of Cellular Biochemistry 77 75-81.

Ray ME, Wistoow G, Su YA, Meltzer PS \& Trent JM 1997 AIM1, a novel non-lens member of the beta-gammacrystallin superfamily, is associated with the control of tumorigenicity in human malignant melanoma. PNAS 94 3229-3234.

Schussheim DH, Skarulis MC, Agarwal SK, Simonds WF, Burns AL, Spiegel AM \& Marx SJ 2001 Multiple endocrine neoplasia type 1: new clinical and basic findings. Trends in Endocrinology and Metabolism 12 173-178.

Speel EJM, Richter J, Moch H, Egenter C, Saremaslani P, Rütimann K, Zhao J, Barghorn A, Roth J, Heitz PU et al. 1999 Genetic differences in endocrine pancreatic tumor subtypes detected by comparative genomic hybridization. American Journal of Pathology 155 1787-1794.

Speel EJM, Scheidweiler AF, Zhao J, Matter C, Saremaslani P, Roth J, Heitz PU \& Komminoth P 2001 Genetic evidence for early divergence of small functioning and nonfunctioning endocrine pancreatic tumors: gain of $9 q 34$ is an early event in insulinomas. Cancer Research $\mathbf{6 1}$ 5186-5192.

Speel EJM, Meier D, Zhao J, Matter C, Muletta-Feurer S, Perren A, Saremaslani P, Schuuring ED, Roth J \& Heitz P 2002 Chromosome 11q losses in sporadic endocrine pancreatic and neuroendocrine tumors indicate the presence of another tumor suppressor gene telomeric of MEN1. Proceedings of the AACR 43636.

Stumpf E, Aalto Y, Höög A, Kjellman M, Otonkoski T, Knuutila S \& Andersson LC 2000 Chromosomal alterations in human pancreatic endocrine tumors. Genes, Chromosomes and Cancer 29 83-87.

Terris B, Meddeb M, Marchio A, Danglot G, Fléjou JF, Belghiti J, Ruszniewsky P \& Bernheim A 1998 Comparative genomic hybridization analysis of sporadic neuroendocrine tumors of the digestive system. Genes, Chromosomes and Cancer 22 50-56.

Tönnies H, Toliat MR, Ramel C, Pape UF, Neitzel H, Berger W \& Wiedenmann B 2001 Analysis of sporadic neuroendocrine tumors of the enteropancreatic system by comparative genomic hybridization. Gut 48 536-541.

Vogelstein B \& Kinzler KW 2004 Cancer genes and the pathways they control. Nature Medicine 10 789-799.

Warren C, James LA, Ramsden RT, Wallace A, Baser ME, Varley JM \& Evans DG 2003 Identification of recurrent regions of chromosome loss and gain in vestibular schwannomas using comparative genomic hybridization. Journal of Medical Genetics 40 802-806.

Wessels PH, Twijnstra A, Kubat B, Ummelen MIJ, Claessen SMH, Sciot R, Merlo A, Ramaekers FCS, Speel EJM \& Hopman AHN 2004 10q25.3 (DMBT1) copy number changes in astrocytoma grades II and IV. Genes, Chromosomes and Cancer 39 22-28.

Wild A, Langer P, Celik I, Chaloupka B \& Bartsch DK 2002 Chromosome $22 \mathrm{q}$ in pancreatic endocrine tumors: identification of a homozygous deletion and potential prognostic associations of allelic deletions. European Journal of Endocrinology 147 507-513.

Yang Y, Gil M, Byun SM, Choi I, Pyun KH \& Ha H 1996 Transforming growth factor-beta 1 inhibits human keratinocyte proliferation by upregulation of a receptortype tyrosine phosphatase R-PTP-kappa gene expression. Biochemical and Biophysical Research Communications 228 807-812.

Yong L, Corradetti MN, Inoki K \& Guan KL 2004 TSC2: filling the GAP in the mTOR signalling pathway. Trends in Biochemical Sciences 29 32-38.

Zhao J, Moch H, Scheidweiler AF, Baer A, Schäffer AA, Speel EJM, Roth J, Heitz PU \& Komminoth P 2001 Genomic imbalances in the progression of endocrine pancreatic tumors. Genes, Chromosomes and Cancer 32 364-372.

Zhuang Z, Vortmeyer AO, Pack S, Huang S, Pham TA, Wang C, Park WS, Agarwal SK, Debelenko LV, Kester M et al. 1997 Somatic mutations of the MEN1 tumor suppressor gene in sporadic gastrinomas and insulinomas. Cancer Research 57 4682-4686.

Zhuang Z, Park WS, Pack S, Schmidt L, Vortmeyer AO, Pak E, Pham T, Weil RJ, Candidus S, Lubensky IA et al. 1998 Trisomy 7-harbouring non-random duplication of the mutant MET allele in hereditary papillary renal carcinomas. Nature Genetics 20 66-69. 
